\title{
Ю.Ю. Рябоконь \\ ХРОНІЧНИЙ ГЕПАТИТ С ЗІ ЗМІШАНОЮ КРІОГЛОБУЛІНЕМІЄЮ: СУЧАСНІ ПІДХОДИ ДО ЛІКУВАННЯ
}

\author{
Запорізький державний медичний університет МОЗ України
}

Висвітлено проблемні питання лікування хворих на ХГС зі змішаною кріоглобулінемією. Показано, що ерадикація вірусу гепатиту $C \in$ головною метою в лікуванні хворих на ХГС зі змішаною кріоглобулінемією. При тяжких фрормах HCV-асоційованого кріоглобулінемічного васкуліту доцільно враховувати можливості патогенетичного лікування.

Ключові слова: хронічний гепатит C, змішана кріоглобулінемія, лікування.

Особливістю хронічної HCV-інсрекції є висока частота розвитку позапечінкових проявів, яка, за даними різних досліджень, складає від 40 до $74 \%$ [1, 2]. У деяких пацієнтів позапечінкові ознаки є першими проявами HCV-інфекції, в інших - розвиваються через декілька років після виявлення збудника. Позапечінкові прояви хронічної HCV-інорекції можуть перебігати як латентно, так і у вигляді яскравих клінічних симптомів або самостійних захворювань, домінуючи в клінічній симптоматиці, а в ряді випадків визначати прогноз захворювання $[2,3]$. Тому хворі на хронічний гепатит C (ХГС) є досить складною категорією пацієнтів не лише в діагностичному плані, але й виборі тактики лікування.

На сьогодні роль HCV як провідного етіологічного чинника $є$ доведеною у розвитку змішаної кріоглобулінемії та обумовленого нею кріоглобулінемічного васкуліту $[4,5]$. Більше 50 \% пацієнтів мають клінічну маніфестацію змішаної кріоглобулінемії від вираженої загальної слабкості до тяжких її проявів з ураженням шкіри і нирок [6].

3 урахуванням ролі HCV в розвитку змішаної кріоглобулінемії, ерадикація вірусу гепатиту C $€$ головною метою в лікуванні хворих на ХГС зі змішаною кріоглобулінемією [7]. В терапії цих хворих обґрунтовано вирішення питання щодо призначення противірусної терапії (ПВТ), а саме інтерферону або пегінтерферону в комбінації 3 рибавірином, за загальноприйнятими схемами. На жаль, на сьогодні відсутні багатоцентрові дослідження щодо ефективності ПВТ ХГС у хворих з наявністю змішаної кріоглобулінемії, тому що цей позапечінковий прояв був одним 3 критеріїв виключення пацієнтів з багатоцентрових досліджень. Дані сучасної літератури щодо застосування ПВТ у хворих на ХГС зі змішаною кріоглобулінемією обмежені дослідженнями ефективності лікування в невеликих групах пацієнтів.

Після курсу ПВТ інтерфероном- $\alpha$ в комбінації з рибавірином регрес клінічних проявів змішаної кріоглобулінемії дослідники відзначали у 50-70 \% пацієнтів, що мало високу кореляцію зі зниженням кількісного вмісту HCVRNA [7], при цьому клінічні ознаки HCV-асоційованого кріоглобулінемічного васкуліту після успішної ПВТ залишалися лише в окремих пацієнтів [8]. Позитивний ефект ПВТ із застосуванням інтерферону- $\alpha$ в лікуванні хворих на ХГС зі змішаною кріоглобулінемією пояснюється не лише його роллю в фрормуванні вірусологічної відповіді, а й його антипроліферативними властивостями, впливом на В-клітини, що приводить до зменшення продукції IgМ-ревматоїдного фрактору, а й стимулюючим впливом на макрофрагально-опосередкований кліренс імунних комплексів [9]. Зазначені ефректи інтерферону- $\alpha$ дозволяють досягти клінічного ефекту щодо регресу проявів HCV-асоційованої кріоглобулінемії навіть у випадках відсутності вірусологічної відповіді [9].

На сьогодні у вітчизняній літературі з'являються дослідження щодо визначення ефективності подвійної ПВТ у лікуванні ХГС у хворих з наявністю кріоглобулінемічного синдрому. Так, в дослідженні [10] показано, що наявність субклінічного, легкого або середньої тяжкості кріоглобулінемічного синдрому у хворих на ХГС практично не впливає на досягнення стійкої вірусологічної відповіді на стандартну ПВТ, ефективність у хворих 3 субклінічним перебігом кріоглобулінемічного синдрому склала 81,8 \%, клінічно маніфрестним - 75,0 \%. При цьому досягнення стійкої вірусологічної відповіді супроводжувалося нормалізацією рівнів кріоглобулінів у крові (у 62,5 \% пролікованих з клінічно маніфестним та у 63,6 \% - із субклінічним кріоглобулінемічним синдромом).

В нашому дослідженні [11] було встановлено, що формування ранньої вірусологічної відповіді на подвійну ПВТ у хворих на ХГС зі змішаною кріоглобулінемією 
відбулося у 57,9 \% пацієнтів і супроводжувалося зменшенням вмісту змішаних кріоглобулінів, при цьому у хворих з ранньою вірусологічною відповіддю на ПВТ вміст змішаних кріоглобулінів у сироватці крові був достовірно нижчим, на відміну від пацієнтів без такої відповіді на лікування.

На ефрективність противірусного лікування хворих на ХГС зі змішаною кріоглобулінемією негативно впливає високий рівень кріокриту та наявність клінічних ознак кріоглобулінемічного васкуліту. При цьому ПВТ найбільш есрективна за умов початкових проявів кріоглобулінемічного васкуліту (тріада Мельтцера: слабкість, артралгії, пурпура). Найбільш резистентні до цього лікування хворі з ураженням нирок й периферичної нервової системи в рамках HCV-асоційованого кріоглобулінемічного синдрому $[12,13]$.

Вивчення застосування інгібіторів протеаз HCV в лікуванні хворих з HCV-асоційованим геморагічним кріоглобулінемічним васкулітом показало, що через 3 місяці лікування потрійна ПВТ була високо ефективною в досягненні як вірусологічної відповіді, так і клінічної відповіді, однак у високому відсотку мали місце небажані побічні ефекти ПВТ (>80 \% - анемія, >50 \% - інфекційні ускладнення) [14].

Однак слід зазначити, що на тлі ПВТ можливі загострення кріоглобулінемічного васкуліту, насамперед це стосується ураження нирок, нейропатії та виразковонекротичного васкуліту. Крім цього, на тлі етіотропного лікування хворих на ХГС з наявністю біохімічних ознак змішаної кріоглобулінемії можлива й манісрестація клінічних проявів HCV-асоційованого кріоглобулінемічного васкуліту [15-17].

В ряді випадків етіотропне лікування хворих на ХГС 3 наявністю змішаної кріоглобулінемії слід поєднувати із патогенетичними засобами [18]. В патогенетичному лікуванні кріоглобулінемічного васкуліту на сьогодні особливу увагу приділяють застосуванню ритуксимабу - химерних моноклональних антитіл, які специфічно зв'язуються із трансмембранним антигеном CD20 на поверхні В-лімфоцитів, обумовлюючи комплемент- й антитілозалежну цитотоксичність, а також індукцію апоптозу лімфроцитів. Ритуксимаб може бути застосований в якості терапії першої лінії у хворих з HCV-асоційованим кріоглобулінемічним васкулітом, при цьому позитивна динаміка щодо регресу проявів кріоглобулінемічного нефриту, нейропатії, виразково-некротичного васкуліту досягається при тривалому, протягом 18 місяців, лікуванні [19].

Призначення імуносупресантів (глюкокортикостероїди, цитостатики) в поєднанні з плазмаферезом $€$ необхідним при швидко прогресуючому перебігу HCVасоційованого кріоглобулінемічного васкуліту та станів, що загрожують життю пацієнтів: при генералізованому васкуліті з ураженням судин нирок, легень, травного каналу, периореричної нервової системи з розвитком моторних порушень, виразково-некротичного васкуліту, головного мозку. Призначення імуносупресантів у поєднанні з плазмаферезом пригнічує імунне запалення, продукцію автоантитіл, утворення та депонування в судинах імунних комплексів [20, 21].

У сучасній літературі немає єдиних рекомендацій щодо етіопатогенетичного лікування пацієнтів з HCVасоційованою кріоглобулінемією та пов'язаними 3 нею симптомами, проте різні дослідники пропонують ті чи інші критерії призначення лікування, спрямованого як на пригнічення вірусної реплікації, так і на зменшення імунного запалення.

Ряд авторів пропонують подібну стратегію лікування хворих на ХГС $з$ наявністю змішаної кріоглобулінемії [21, 22]:

- при легкому та середньотяжкому перебігу захворювання (пурпура, артралгії, полінейропатія) рекомендована ПВТ (пегільований інтерферон-а в поєднанні 3 рибавірином);

- при тяжкому перебігу (прогресування ураження нирок, шкірні виразки) рекомендовано призначення ПВТ на тлі лікування ритуксимабом;

- при загрожуючих життю станах (швидко прогресуючий нефрит, залучення в процес легень, шлунково-кишкового тракту) призначаються імуносупресивні засоби (стероїди, циклофросфамід), плазмаферез та/ або ритуксимаб.

При зниженні активності васкуліту рекомендується зменшення доз імуносупресантів, спроба їх скасування та вирішення питання щодо можливості проведення ПВТ [23].

На відміну від цих рекомендацій, автори [24] вважають, що ПВТ може бути призначена лише в період ремісії HCV-асоційованого кріоглобулінемічного васкуліту. За наявності ж клінічних ознак останнього пропонують:

- при середньотяжкому перебігу (пурпура, артралгії, периферична сенсорна полінейропатія) слід призначати низькі дози стероїдів;

- за наявності тяжчих проявів васкуліту (шкірні виразки, моторна полінейропатія, гломерулонефрит) слід призначати високі дози стероїдів, плазмасререз, а за відсутності ефекту циклофосфамід.

В останні роки з'являються повідомлення щодо есрективності застосування інших імунотропних засобів, зокрема рекомбінантного інтерлейкіну-2. В дослідженні [25] продемонстровано ефективність інтерлейкіну-2 в лікуванні хворих з HCV-індукованим кріоглобулінемічним васкулітом, які не відповіли на попередню ПВТ та лікування ритуксимабом й не мали показань до призначення 
імуносупресивних засобів. За результатами цієї терапії у хворих відбувалося вірогідне зменшення сироваткового рівня кріоглобулінів, підвищувався рівень комплементу C4, а також реєструвався регрес провідних симптомів васкуліту у більшості пацієнтів.

Серед методів імунотропної терапії вітчизняними дослідниками [26] запропоновано новий спосіб лікування хворих на ХГС з проявами системного васкуліту, пов'язаного зі змішаною кріоглобулінемією, шляхом внутрішньошкірної імунізації автолейкоцитами, який може бути застосований самостійно або в комплексній терапії.

Складність патогенетичних механізмів, які є основою фрормування позапечінкових проявів ХГС, обумовлює певне обґрунтування призначення засобів патогенетичного лікування. При ХГС є чимало патогенетичних аспектів, що обумовлюють ураження ендотелію. 3 одного боку, певну роль відіграє розвиток HCV-асоційованого КГЕ-васкуліту, що пов'язане з відкладанням в їх стінці імунних депозитів, основою яких $є$ кріоглобуліни. 3 іншого боку, доведена можливість низького рівня реплікації HCV в деяких тканинах нелімфоїдного походження, в тому числі в ендотелії судин [27]. Тому в лікуванні хворих на ХГС з позапечінковими проявами, зокрема зі змішаною кріоглобулінемією, патогенетично обґрунтованим й ефективним є застосування препарату з ангіопротекторною дією - L-аргініну. За результатами наших досліджень [28], ендотеліальна дисфрункція реєструється більш ніж у половини хворих на ХГС, поєднується із низьким вмістом L-аргініну в сироватці крові та відіграє певну роль в активності гепатиту та формуванні позапечінкових проявів захворювання. Ефективність патогенетичної терапії з включенням L-аргініну підтверджується зниженням вмісту ендотеліну-1, підвищенням вмісту нітритів у сироватці крові та відновленням показника реактивної гіперемії плечової артерії на тлі лікування [29].

За наявності клінічних ознак HCV-асоційованого кріоглобулінемічного васкуліту в комплекс патогенетичного лікування слід включати засоби для корекції порушень мікроциркуляції [13], зокрема пентоксифрілін, за необхідності гепарин, ксантинолу нікотинат.

При виборі гепатопротективного препарату особливу увагу слід звернути на засоби, що володіють комплексною дією, зокрема препарати урсодезоксихолевої кислоти (УДХК). За даними літератури [30], прогресування васкуліту тісно пов'язано з прогресуванням оріброзу печінки. У більшості хворих судинна пурпура вперше з'являється або часто рецидивує на стадіях фріброзу печінки F3-4. При цьому, як правило, відсутній зв'язок між загостренням судинної пурпури та активністю вірусної інфекції. Призначення УДХК робить позитивний вплив не тільки на біохімічні показники цитолізу і холестазу, але й позитивно впливає на співвідношення сироваткових маркерів фріброгенеза і фріброліза. Крім того, імуномодулюючі ефекти УДХК виявляються в зменшенні експресії антигенів HLA на поверхні гепатоцитів, що запобігає активації цитотоксичних лімсоцитів, зменшує продукцію автоантитіл, стимулює вироблення інтерферону- $\alpha$ гепатоцитами [31].

Важливим при виборі тактики лікування хворих на ХГС $€$ не лише оцінка наявності та ступеня виразності кріоглобулінемічного синдрому, але й інших позапечінкових проявів, що не пов'язані з кріоглобулінемією, проте за ступенем тяжкості можуть бути більш серйозними та обумовлювати протипоказання до призначення ПВТ. Серед таких позапечінкових проявів слід зазначити автоімунний тиреоїдит, цукровий діабет 2-го типу, В-клітинну неходжкінську лімфрому, імунну тромбоцитопенію тощо. В сучасній літературі $є$ лише поодинокі повідомлення про застосування ПВТ у хворих на ХГС з наявністю В-клітинної неходжкінської лімфоми [32], імунної тромбоцитопенії [33], синдромом Шегрена [34].

Таким чином, хворі на ХГС зі змішаною кріоглобулінемією залишаються однією з найскладніших категорій пацієнтів для лікування. Ерадикація вірусу гепатиту C $\epsilon$ головною метою в лікуванні хворих на ХГС зі змішаною кріоглобулінемією. За умов тяжких фрорм HCVасоційованого кріоглобулінемічного васкуліту доцільно враховувати можливості патогенетичного лікування.

\section{Література}

1. Stefanova-Petrova D.V. Chronic hepatitis $C$ virus infection: prevalence of extrahepatic manifestations and association with cryoglobulinemia / D.V. Stefanova-Petrova // J. Gastroenterol. - 2007. - Vol. 13. - P. 6518-6528.

2. Sterling R.K. Extrahepatic manifestations of hepatitis C virus / R.K. Sterling, S. Bralow // Curr. Gastroenterol. Rep. - 2006. - Vol. 8. -P. 53-59.

3. Carles E.D. Hepatitis C virus-induced cryoglobulinemia / E.D. Carles, L.B. Dustin // Kidney International. - 2009. - Vol. 76. P. 818-824.

4. The cryoglobulinaemias / [M. Ramos-Casals, J.H. Stone, M.C. Cid et al.] // Lancet. - 2012. - Vol. 379. - P. 348-360.

5. Role of the receptor for the globular domain of C1q protein in the pathogenesis of hepatitis $C$ virus related cryoglobulin vascular damage / [D. Sansonno, F.A. Tucci, B. Ghbrehiwet et al.] // J. Immunol. - 2009. - Vol. 183, N 9. - P. 6013-6020.

6. Extrahepatic manifestations of chronic hepatitis C. MULTIVIRC Group. Multidepartment Virus C / [P. Cacoub, T. Poynard, P. Ghillani et al.] // Arthritis Rheum. - 1999. - Vol. 42. - P. 2204-2212.

7. Sustained response to interferon-alpha or to interferon-alpha plus ribavirin in hepatitis $C$ virus associated symptomatic mixed cryoglobulinaemia / [J.L. Calleja, A. Albillos, R. Moreno-Otero et al.] // Aliment Pharmacol. Ther. - 1999. - Vol. 13. - P. 1179-1186.

8. Persistent cryoglobulinemic vasculitis following successful treatment of hepatitis C virus / [J.W. Levine, C. Gota, B.J. Fessler et al.] // J. Rheumatol. - 2005. - Vol. 32. - P. 1164-1167.

9. Craxi A. Hepatitis C virus (HCV) infection: a systemic disease / A. Craxi, G. Laffi, A.L. Zignego // Mol. Aspects Med. - 2008. - Vol. 29. - P. 85-95. 
10. Кондратюк Л.О. Кріоглобулінемічний синдром у хворих 3 хронічним гепатитом С і можливості його корекції: Автореф. дис. ... к. мед. н. / Л.О. Кондратюк. - Київ, 2015. - 22 с.

11. Рябоконь Ю.Ю. Хронічний гепатит С з позапечінковими проявами: клініко-патогенетична роль нейрогуморальної та ендотеліальної дисфункції, оптимізація діагностики та лікування: Автореф. дис. ... д. мед. н. / Ю.Ю. Рябоконь. - Тернопіль, 2015. $-40 \mathrm{c}$.

12. Cacoub P. Interferon-alpha and ribavirin treatment in patients with hepatitis $C$ virus-related systemic vasculitis / P. Cacoub, O. Lidove, T. Maisonobe // Arthritis Rheum. - 2002. - Vol. 46. - P. 3317-3326.

13. Della Rossa A. Treatment of chronic hepatitis $C$ infection with cryoglobulinemia / A. Della Rossa, A. Tavoni, C. Baldini // Curr. Opin. Rheumatol. - 2002. - Vol. 13. - P. 231-237.

14. Peg-IFN-alpha/Ribavirin/Protease inhibitor combination is highly effective in HCV-mixed cryoglobulinemia vasculitis / [D. Saadoun, S. Pol, P. Lebray et al.] // Hepatology. - 2012. - Vol. 56. - Abstract A790.

15. Batisse D. Sustained exacerbation of cryoglobulinemia-related vasculitis following treatment of hepatitis $C$ with peginterferon-alfa / D. Batisse, M. Karmochkine // Eur. J. Gastroenterol. Hepatol. - 2004. - Vol. 16. - P. 701-703.

16. Beuthien W. Vasculitis complications of interferon-alpha treatment for chronic hepatitis $\mathrm{C}$ virus infection: case report and review of the literature / W. Beuthien, H.U. Mellinghoff // Clin. Rheumatol. - 2005. - Vol. 30. - P. 369-371.

17. Kimyai-Asadi A. Mixed cryoglobulinemia secondary to interferon therapy for hepatitis C: case report and review of the literature / A. Kimyai-Asadi, K. Gohar, P. Kang // J. Drugs Dermatol. - 2002. - Vol. 1. - P. 72-75.

18. Cacoub P. PEGylated interferon alfa $2 \mathrm{~b}$ and ribavirin treatment in patients with hepatitis $C$ virus-related systemic vasculitis / P. Cacoub D. Saadoun, N. Limal // Arthritis Rheum. - 2005. - Vol. 52. - P. 911-915.

19. Roccatello D. Long-term effects of anti-CD monoclonal antibody treatment of cryoglobulinaemic glomerulonephritis / D. Roccatello, S. Baldovino, D. Rossi // Nephrol. Dial. Transplant. - 2004. - Vol. 19 - P. 3054-3061.

20. Ramos-Casals M. Therapeutic management of extrahepatic manifestations in patients with chronic hepatitis C virus infection / M. Ramos-Casals, O. Trejo, M. Garcia-Carrasco // Reumatology. 2003. - Vol. 42. - P. 818-828.

21. Saadoun D. Therapeutic strategies in patients with HCV associated MC vasculitis / D. Saadoun // Reumatology. - 2007. - Vol. 46. - P. 1234-1242.

22. Ferri C. Mixed cryoglobulinemia / C. Ferri // Orph. J. Rare Dis. - 2008. - Vol. 3, N 25. - P. 2365-2370.

23. Cacoub P. Treatment of hepatitis $C$ virus-related systemic vasculitis / P. Cacoub, D. Saadoun, D. Sene // J. Rheumatol. - 2005 - Vol. 32. - P. 2078-2082.

24. Schamberg N.J. Hepatitis $C$ virus-related mixed cryoglobulinemia: pathogenesis, clinical manifestations, and new therapies / N.J. Schamberg, G.V. Lake-Bakaar // Gastroenterol. Hepatol. - 2007. - Vol. 3, N 9. - P. 695-703.

25. Saadoun D. Regulatory T-cell responses to low-dose interleukin-2 in HCV-induced vasculitis / D. Saadoun, M. Rosenzwajg, F. Joly // N. Engl. J. Med. - 2011. - Vol. 365. - P. 2067-2076.
26. Деклараційний патент на винахід № 13766. Україна. Спосіб терапії хворих на хронічні вірусні гепатити В і С з проявами системних васкулітів / Б.А. Герасун, В.В. Чопяк, О.Б. Ворожбит. Опубл. 17.04.06, Бюл. № 4.

27. Weng W-K. Hepatitis C virus (HCV) and lymphomagenesis / W-K. Weng, S. Levy // Leukemia Lymphoma. - 2003. - Vol. 44. P. 1112-1113

28. Андрейчин М.А. Роль ендотеліальної дисфункції в перебігу хронічної HCV-інфекції та її корекція препаратом L-аргініну / М.А. Андрейчин, Ю.Ю. Рябоконь // Інфекційні хвороби. - 2012. № 1 (67). - С. 31-39.

29. Деклараційний патент на корисну модель 71715. Україна, МПК (2012.01). Спосіб вибору тактики патогенетичного лікування хронічного гепатиту С / Рябоконь Ю.Ю. - № u 2012 00010; Заявл. 03.01.2012; Опубл. 25.07.2012. - Бюл. № 14

30. Forton D.M. Hepatitis $C$ and cognitive impairment in a cohort of patient with mild liver disease / D.M. Forton, H.C. Thomas, C.A. Murphy // Hepatology. - 2002. - Vol. 35. - P. 433-439.

31. Андрейчин М.А. Урсодезоксихолева кислотау патогенетичній терапії хронічних захворювань печінки / М.А. Андрейчин, О.В. Рябоконь // Сучасні інфекції. - 2007. - № 1. - С. 30-35.

32. Vallisa D. Role of anti-hepatitis $\mathrm{C}$ virus (HCV) treatment in HCV-related, low-grade, B-cell, non-Hodgkin's lymphoma: a multicenter Italian experience / D. Vallisa, P. Bernuzzi, L. Arcaini // J. Clin. Oncol. - 2005. - Vol. 23. - P. 468-473.

33. Benci A. Thrombocytopenia in patients with HCV-positive chronic hepatitis: efficacy of leukocyte interferon-alpha treatment / A. Benci, M. Caramani, D. Tacconi // Int. J. Clin. Pract. - 2003. Vol. 57. - P. 17-19.

34. Doffoel-Hantz V. Evolution of Sjogren syndrome associated with hepatitis $C$ virus when chronic hepatitis $C$ is treated by interferon or the association of interferon and ribavirin / V. Doffoel-Hantz, V. Loustand-Ratti, M. Ramos-Casala // Rev. Med. Intern. - 2005. Vol. 26. - P. 88-94

\section{CHRONIC HEPATITIS C WITH MIXED CRYOGLOBULINEMIA: MODERN APPROACHES TO TREATMENT}

\author{
Yu.Yu. Riabokon
}

SUMMARY. Problematic issues of treatment of patients with chronic hepatitis $C$ with mixed cryoglobulinemia are presented. It is shown that the eradication of virus hepatitis $C$ is a main aim in treatment of patients with chronic hepatitis $C$ with mixed cryoglobulinemia. At severe forms of the HCV-associated cryoglobulinema vasculitis it is expedient to consider possibilities of pathogenetic treatment.

Key words: chronic hepatitis C, mixed cryoglobulinemia, treatment.

Отримано 31.03.2016 p. 